\title{
The Influence of Marketing Communication Through \#TokopediaWIB TV Show Event on Brand Loyalty of Tokopedia (A Survey on K-Pop Fans)
}

\author{
Sherin Angela ${ }^{1 *}$ Sinta Paramita ${ }^{1}$ \\ ${ }^{1}$ Faculty of Communication Science, Universitas Tarumanagara, Jakarta Indonesia \\ ${ }^{*}$ Corresponding author. Email: sherin.915170039@stu.untar.ac.id
}

\begin{abstract}
The high competition between marketplaces certainly encourages each marketplace to keep innovating so that despite the many marketplace choices out there, people still use them loyally. One of the ways is by designing a marketing communication strategy. This study discussed one of the marketing communication forms through events, namely \#TokopediaWIB TV Show which affects brand loyalty. The purpose of this study was to find out the level of brand loyalty formed within the audiences and to discover how much influence this event had on Tokopedia's brand loyalty. The approach used in this research is a quantitative approach with a survey method. The population for this study was determined based on the market segmentation that Tokopedia is aiming for, namely K-pop fans, and the number of samples in this study was 120 respondents based on the statement of Hair et al. The sampling technique used in this study is non-probability sampling with purposive sampling. The data in this study were analyzed using descriptive analysis, normality test, simple linear regression analysis, coefficient of determination analysis, and T-test. In testing the validity of the data, this study used validity and reliability tests. Based on the results of data analysis, the audience's assessment of this event was very good and the audience had a relatively good level of brand loyalty, namely likes the brand. This event has a significant effect on Tokopedia's brand loyalty by $30.7 \%$ and the rest is influenced by other variables outside of this study.
\end{abstract}

\section{Keywords: Brand Loyalty, Event, Marketing Communication}

\section{INTRODUCTION}

The current era of globalization has encouraged the rapid development of technology. The development of this technology is certainly used by various parties to change the order of human life to become increasingly modern. One example is the buying and selling transactions that were previously carried out conventionally now slowly shifted to online buying and selling transactions. The marketplace is a website that facilitates or connects sellers with buyers via the internet. In www.price.co.id it is said that the marketplace in Indonesia continues to grow every year as seen from the position of the marketplace that is most superior in the second quarter of 2020. The rapidly growing marketplace certainly encourages competition between marketplaces, one of which is between Shopee and Tokopedia. Both marketplaces are competing to become the number one marketplace in Indonesia. Based on the results of research by the iPrice institute, Tokopedia occupied the first position in the first quarter to the third quarter of 2019 , but in the fourth quarter of 2019 to the second quarter of 2020, Tokopedia experienced a decline to second place.

Tokopedia has certainly taken various innovations to return to its first position in the marketplace in Indonesia, one of which is through a marketing communication strategy. Kotler and Keller define marketing communication as a means for companies to persuade, remind, and inform consumers, either directly or indirectly, about the products and brands being sold [1]. According to Kotler and Armstrong, the marketing communication mix consists of Advertising, Sales Promotion, Personal Selling, Public Relations, and Direct Marketing [2]. Public Relations who carry out marketing communications are known as Marketing Public Relations [3].

Tokopedia runs marketing communications through one of its Marketing Public Relations activities, namely events. [4] defines an event as a special ritual, presentation, appearance or service that is deliberately planned and made to signify a special opportunity that aims to achieve certain social, cultural, or corporate goals. The \#TokopediaWIB TV Show event was designed with attention to its psychographic segmentation target, namely K-pop fans, where according [5] this segmentation is carried out based on social class, lifestyle, and personal character. The lifestyle of young people in Indonesia is currently being dominated by the Korean wave, so Tokopedia took advantage of this opportunity by designing events that focus on K-pop fans. 
Of course, this event must be designed as well as possible and be different from previous events. Wood and Masterman [6] identified that a successful event, especially a marketing event that focuses on the participant's experience, has seven event attributes, namely involvement, interaction, immersion, intensity, individuality, innovation, and integrity. Events that have fulfilled every attribute of the event can be a company communication medium in influencing the way consumers perceive the brand positively and can foster brand loyalty. According to [7] brand loyalty is a happy attitude towards a brand which is represented in a consistent purchase of the brand all the time. This is in line with Getz's statement [4] that events organized by a company can affect brand awareness and loyalty. In addition, research from Azusa Rahman Wijaya [8] has proven that the marketing communication strategy through event marketing used by Bintang beer is one of the most important ways among other strategies in maintaining brand loyalty and similar research [9] also proves that special events are influential in building retail store brand loyalty among generation $\mathrm{Z}$. On the other hand, if the event is not designed properly, the event will only be an activity that costs money.

Based on this explanation, the researcher became interested in examining how much influence marketing communications through the \#TokopediaWIB TV Show event has on Tokopedia brand loyalty by focusing on experience from the participant's point of view. Researchers chose the point of view of the majority of the event audience, namely K-pop fans, because this event itself is designed to be more focused on K-pop, seen from every month that famous boy or girl groups from South Korea are presented as the main guest stars. Researchers also focused more on BTS and Twice Fans based on the reason that among all the guest stars invited to the \#TokopediaWIB TV Show event from July 2020 to October 2020, BTS and Twice are the most popular according to research results from Korean Business Research.

\subsection{Related Work}

\subsubsection{The Effect of Marketing Communication through Events and Ads on Shopee Brand Images.}

This study proves that marketing communication activities through events and advertisements affect the brand image of Shopee either partially or collectively. This study uses the theory of marketing communication, events, advertising, e-commerce, and brand image. This study succeeded in examining that there was a very strong relationship of 0.861 between the event variable (X1) and the advertising variable (X2) on the image variable (Y) where it was based on the results of the correlation coefficient test. This strong relationship is increasingly supported by the coefficient of determination test results that $74.1 \%$ of events and advertisements affect the Shopee brand image and the remaining $25.9 \%$ are influenced by other variables

\subsubsection{The Effect of Arema Goes to School as Event Marketing to Arema FC's Brand Image}

This research uses explanative quantitative research with survey methods. The theory used in this research is the event theory put forward by Wood and Masterman, namely $7 \mathrm{i}$ event attributes and Keller brand image theory. The results of the study used a simple linear regression analysis technique so that a regression equation was obtained, namely, $\mathrm{Y}=3.852+0.216 \mathrm{X}$ which means that if the marketing event is worth 0 , the brand image will increase by 0.216 , it can be concluded that there is an effect of Arema Goes To School event marketing on the brand image Arema FC.

\subsubsection{The Influence of Event to The Brand Loyalty of Retail Store Among Z Generation (Survey to Student of University Cluster in Jakarta)}

This study explains the effect of special events on brand loyalty by using Tom Duncan's special event theory and Jill Griffin's theory of brand loyalty. This research is explanative with the method used is a survey with cluster sampling technique. This study conducted a Pearson correlation test and obtained a value of 0.467 which means that there is a sufficient relationship between variable $\mathrm{X}$ and variable $\mathrm{Y}$. This study also conducted a simple linear regression test and found that there was an effect of $21.8 \%$ between special events on brand loyalty stores. retail among Generation Z.

\subsection{Our Contribution}

The benefits of research that are expected to provide knowledge in the field of communication science Marketing communication related to events and brand loyalty, can be a reference for study and development for communication science students who want to carry out similar research related to marketing communications of a company, are expected to be useful and become one of the inputs for Tokopedia, especially in developing better marketing communications in the future, and it is also expected to be an illustration for companies that want to mix marketing communications or have a similar market segmentation.

\subsection{Paper Structure}

The rest of the paper is organized as follows. Section 2 introduces the theories and frameworks that support this research, starting from public relations, marketing communication, marketing public relations activities, events, and brand loyalty. Section 3 presents the research methods used in this study ranging from research approaches, research methods, population and samples, sampling techniques, number of respondents, data validity techniques, and data processing techniques. Then in section 
4, the method in section 3 is realized so that the test results are obtained and to find out whether the hypothesis is accepted or rejected. Section 5 concludes the research results and suggestions for future research.

\section{BACKGROUND}

\subsection{Public Relations}

Cutlip and the Center define Public Relations as a management function that assesses public attitudes, identifies policies and organizational procedures for the public interest, and plans a program of activities and communications aimed at gaining public understanding and support [10]. Frank Jefkins defines Public Relations as all forms of planned communication, both internal and external communication, between an organization and all its audiences in an effort to achieve specific goals based on mutual understanding [4]. In conclusion, Public Relations is a communication planning of an organization to the public both internally and externally by assessing public attitudes, identifying and planning a program with the aim of gaining public understanding and support.

\subsection{Marketing Communication}

Marketing communication is a form of communication that provides marketing strategies to reach a bigger market [11]. There are four objectives of marketing communication delivered by Kotler and Keller [11], which is to build needs based on category, increase brand awareness, grow brand attitude, and create brand purchase intentions.

Public Relations plays an important role in marketing communication activities, as stated by Jefkins, conventional marketing models alone will not be sufficient to deal with current marketing competencies so that additional Public Relations is needed to face increasingly fierce competition [12]. Philip Kotler is the first to use the mega marketing concept, which is a combination of Public Relations and Marketing Mix which serves to add value to a product through a unique ability to give product message credibility [12]. Later on Thomas L. Harris in his book entitled "The Marketer's Guide to Public Relations" named this combination concept as Marketing Public Relations. Thomas L. Harris defines Marketing Public Relations as a process of planning and evaluating programs that drive purchases and customers through communication of credible information and impressions that identify companies and their products with the needs of customer attention [10].

It can be concluded that a combination of public relations and marketing mix or known as Marketing Public Relations is a a combination program that supports the marketing of a product or company through communication so that it produces a credible message to the product and company.

\subsection{Marketing Public Relation Activities}

There are seven activities that can be done in the Marketing Public Relations program according to Kotler, et al [4], namely: (1) Publications, the company uses published material in both visual and audio form to achieve and influence its targets. (2) Events, the company holds events that reach its target audience so that it can attract public attention and increase awareness of the products or services offered by the company. (3) Sponsorship, the company sponsors certain events that aim to market the company's products or brands. (4) News, a professional Public Relations must be able to create and plan events that are unique and in accordance with the products of the company, so that it can attract media attention to read press releases and attend press conferences held by the company and publish the event in news form. (5) Speeches, company executives liaise with the mass media in order to provide statements about the condition of the company, answer questions from the media, and build and create a positive company image. (6) Public Service Activities, the company contributes both money and time for positive things. (7) Identity Media, companies must create visual identities such as company logos, brochures, business cards, stationery, uniforms, and so on as a tool that can make it easier for people to recognize the company.

\subsection{Event}

Noor [13] said that an event is an activity held to commemorate important things throughout human life, both individually and in groups to achieve certain goals and involve the community at a certain time. According to Ima Hardiman [14], Events are special activities designed and held to attract public attention. [4] Defines an event as a special ritual, presentation, appearance or service that is deliberately planned and made to signify a special opportunity that aims to achieve certain social, cultural, or corporate goals. It can be concluded that an event is a series of activities organized by a company or organization to attract public attention and to achieve certain goals of the company or organization.

Tom Duncan [15] explained that the purpose of holding an event is to influence target audiences, associate a brand with a certain activity or lifestyle, reach a wider target, increase public awareness of a brand or company, publish a brand or company to increase audience knowledge. In line with Tom Duncan's statement, event marketing is considered effective in conveying the message of a brand by inviting customers and potential customers to be involved in an event organized by the company [6].

Event marketing according to Coulson and Thomas [6] is a type of event organized by companies with the aim of making the company's name better known and getting a good image from the public. Duncan defines event marketing as an activity that connects a brand with sports, entertainment, or social activities (public activities) that generate high interest so that it can provide reciprocity to companies to advertise the company [6]. 
Research [6] proves that in an event there are elements of communication in the process. Communication elements according to Lasswell [16] consist of communicators, messages, media, communicants, and effects.

According to Wood and Masterman [6] in identifying the success of an event, especially event marketing that focuses on the experience of participants, it has seven event attributes, namely: (1) Involvement, seeing a participant's emotional involvement with brands, events and experiences. (2) Interaction, participant interaction with brand ambassadors, performers in accordance with the target and company image so that the company message can be accepted by participants. (3) Immersion, the event avoids distractions or things that make participants disturbed or the event successfully delivers an effective message. (4) Intensity, the event must be memorable or easy to remember and have a high impact (high impact). (5) Individuality, this event is unique, different from previous events that have been held or from other events. (6) Innovation, positioning events according to consumer needs and have a creative level of content, place, time, and segmentation. (7) Integrity, the event that is held can provide an advantage and form a value in which the participants give a positive response.

\subsection{Brand Loyalty}

As stated by Getz [4], an event organized by a company can affect brand awareness and loyalty. According to [7] brand loyalty is a happy attitude towards a brand which is represented in a consistent purchase of the brand all the time.

The level of brand loyalty in the book Brand Equity Ten quoted by Durianto [17] that must be considered are: (1) Switcher / Price buyer, customers who are at the most basic level of loyalty where at this level any brand is considered adequate and plays a very small role in purchasing decisions. The visible characteristic of this type of customer is that they buy a product because it is cheap. (2) Habitual buyers are buyers who make purchases on a brand because of habit factors. As long as the buyer does not experience dissatisfaction in consuming a product brand, the buyer has no compelling reason to buy another product brand or switch brands, especially if the transition requires effort, expense, or another sacrifice. (3) Satisfied buyers, category of buyers who are satisfied with the brands they consume. However, they may change brands at the expense of switching costs, such as time, costs or risks arising from their switching. (4) Likes the brand, category of buyers who really like the brand. Liking is based on associations related to symbols, a series of previous experiences with the brand, or perception of high quality. (5) Committed buyer, loyal buyer category. They have pride in using a brand. An obvious feature in this category is the buyer's action to recommend or promote the brand that he uses to others. According to Jill Griffin [9], the characteristics of purchases that indicate brand loyalty are: (1) Make repeat purchases regularly, consumers can be categorized as having brand loyalty if consumers make purchases no less than twice for the same product or service within a certain time. (2) Buy cross-line products and services, an indication of consumers who have brand loyalty can also be seen if consumers show an intention to try other products or services offered by the company. (3) Referring to others, consumers provide positive information about a product or service which is then used as an indicator of consumers who are loyal to the brand. The act of referring a brand to others shows that consumers are satisfied with the brand and acts as a brand evangelist. (4) Shows immunity from the attraction of the competitors, the attractiveness of competitors can be in the form of lower prices, discounts, new variants, promos, etc., which can often influence consumers to switch to other brands. Consumers who have more preference for a number of products or services offered and show reluctance to switch to other products or services indicate that consumers have become loyal consumers of the brand.

\subsection{Framework}

\begin{tabular}{|c|c|}
\hline $\begin{array}{c}\text { Independend Variable (X) } \\
\text { Event }\end{array}$ & $\begin{array}{c}\text { Dependent Variable (Y) } \\
\text { Brand Loyaty }\end{array}$ \\
\hline $\begin{array}{l}\text { 1. Involvement } \\
\text { 2. Interaction } \\
\text { 3. Immersion } \\
\text { 4. Intensity } \\
\text { 5. Individuality } \\
\text { 6. Innovation } \\
\text { 7. Integrity } \\
\text { Wood dan Masterman } \\
\text { (Cahyani, 2017) }\end{array}$ & $\begin{array}{l}\text { 1. Make repeat purchases } \\
\text { regularly } \\
\text { 2. Buy cross-line products } \\
\text { and services } \\
\text { 3. Referring to others } \\
\text { 4. Shows immunity from } \\
\text { the attraction of the } \\
\text { competitors } \\
\text { Griffin (Setyanto, 2018) }\end{array}$ \\
\hline
\end{tabular}

Figure 1 Framework

In the framework scheme above, it can be explained that the Tokopedia Marketplace carries out marketing communications through Marketing Public Relations activities by forming a \#TokopediaWIB TV Show event. This event is certainly designed as best as possible and includes the event attributes in it as conveyed by Wood and Masterman regarding the event which was declared successful based on the participant's point of view has seven event attributes (7i) namely Involvement, Interaction, Immersion, Intensity, Individuality, Innovation, and Integrity. A successful event will certainly have a positive impact on the company, one of which is in building the growth of brand loyalty, this is in line with Getz's statement [4] that events organized by a company can affect brand awareness and loyalty. Therefore, the hypotheses to be tested in this study are:

$\mathrm{H}_{0}$ : There is no influence between the \#TokopediaWIB TV Show event on Tokopedia's brand loyalty by K-pop fans in Jakarta. 
$\mathrm{H}_{1}$ : There is an influence between the \#TokopediaWIB TV Show event on Tokopedia's brand loyalty by K-pop fans in Jakarta.

\section{METHODS}

The research approach used in this research is a quantitative approach. Quantitative research is a research method based on the philosophy of positivism that examines certain populations or samples with sampling techniques that are generally carried out randomly and data analysis is quantitative or statistical [18]. The research method used in this research is a descriptive research method in the form of a survey by distributing questionnaires through electronic media, namely, google form. Surveys are a method in quantitative research that is used to obtain data from samples taken from certain populations with data collection techniques through observations that can be realized by interviews or questionnaires and research results tend to be generalized [18].

In this study, the population determined by the researcher was based on the target market segmentation at the \#TokopediaWIB TV Show event, namely K-pop fans. The sampling technique used in this study was a non-probability sampling technique with a purposive sampling type. The number of respondents used in this study is based on the statement of Hair et al [19], namely the number of indicators in the study multiplied by five. There are 24 indicators in this study multiplied by five, which is a total of 120 respondents.

In this study, primary data were obtained through distributing questionnaires with the instrument used in this study in the form of a Likert scale with four intervals (fourpoint Likert Scale). Secondary data were obtained through library research and the internet. Researchers tested the validity of the data using the validity and reliability tests, while in data processing, researchers used the normality test, simple linear regression analysis, a Coefficient test of determination, and t-test.

\section{FINDINGS AND DISCUSSIONS}

This study succeeded in obtaining 120 valid questionnaires with the majority of respondents being female, aged between 17-28 years, and having domiciles spread across DKI Jakarta, namely $36.7 \%$ domiciled in West Jakarta, $27.5 \%$ domiciled in South Jakarta, $17.5 \%$ in East Jakarta, $11.7 \%$ in Central Jakarta, and $6.7 \%$ in North Jakarta. Researchers tested the validity of the data using validity and reliability testing.

\subsection{Validity Test}

Table 1 Event Variable Validity Test Results (X)

\begin{tabular}{ccccc}
\hline Question & R Count & R table & Sig. Value & Result \\
\hline P1 & 0,648 & 0,1793 & 0,000 & VALID \\
P2 & 0,455 & 0,1793 & 0,000 & VALID \\
P3 & 0,616 & 0,1793 & 0,000 & VALID \\
P4 & 0,591 & 0,1793 & 0,000 & VALID \\
P5 & 0,531 & 0,1793 & 0,000 & VALID \\
P6 & 0,559 & 0,1793 & 0,000 & VALID \\
P7 & 0,645 & 0,1793 & 0,000 & VALID \\
P8 & 0,469 & 0,1793 & 0,000 & VALID \\
P9 & 0,642 & 0,1793 & 0,000 & VALID \\
P10 & 0,522 & 0,1793 & 0,000 & VALID \\
P11 & 0,496 & 0,1793 & 0,000 & VALID \\
P12 & 0,700 & 0,1793 & 0,000 & VALID \\
P13 & 0,704 & 0,1793 & 0,000 & VALID \\
P14 & 0,659 & 0,1793 & 0,000 & VALID \\
P15 & 0,564 & 0,1793 & 0,000 & VALID \\
P16 & 0,778 & 0,1793 & 0,000 & VALID \\
P17 & 0,453 & 0,1793 & 0,000 & VALID \\
P18 & 0,496 & 0,1793 & 0,000 & VALID \\
P19 & 0,571 & 0,1793 & 0,000 & VALID \\
P20 & 0,556 & 0,1793 & 0,000 & VALID \\
\hline
\end{tabular}

Table 2 Brand Loyalty Variable Validity Test Results (Y)

\begin{tabular}{ccccc}
\hline Question & R Count & R table & Sig. Value & Result \\
\hline P21 & 0,733 & 0,1793 & 0,000 & VALID \\
P22 & 0,808 & 0,1793 & 0,000 & VALID \\
P23 & 0,810 & 0,1793 & 0,000 & VALID \\
P24 & 0,824 & 0,1793 & 0,000 & VALID \\
P25 & 0,779 & 0,1793 & 0,000 & VALID \\
P26 & 0,804 & 0,1793 & 0,000 & VALID \\
P27 & 0,730 & 0,1793 & 0,000 & VALID \\
P28 & 0,732 & 0,1793 & 0,000 & VALID \\
P29 & 0,678 & 0,1793 & 0,000 & VALID \\
P30 & 0,645 & 0,1793 & 0,000 & VALID \\
P31 & 0,859 & 0,1793 & 0,000 & VALID \\
P32 & 0,834 & 0,1793 & 0,000 & VALID \\
P33 & 0,838 & 0,1793 & 0,000 & VALID \\
P34 & 0,760 & 0,1793 & 0,000 & VALID \\
\hline
\end{tabular}

Based on the results of the event variable validity test (X) in table 1 and the results of the validity test of the brand loyalty variable (Y) in table 2 using the Pearson Product Moment Correlation processed with the help of the SPSS 22 program, it can be seen that all instruments in this study are declared valid as they meet the criteria. As an instrument that is declared valid, the value of the correlation coefficient ( $r$ count) for each question item is greater than the value of $\mathrm{r}$ table where $\mathrm{r}$ table $(\mathrm{df}=\mathrm{n}-2)$ for 120 respondents is 0.1793 . 


\subsection{Reliability Test}

Table 3 Reliability Test Results

\begin{tabular}{ccc}
\hline Variable & Cronbach's Alpha & Result \\
\hline Event $(\mathrm{X})$ & 0,897 & RELIABLE \\
Brand Loyalty $(\mathrm{Y})$ & 0,944 & RELIABLE \\
\hline
\end{tabular}

Based on the results of the reliability test using the Cronbach's Alpha method processed with the help of the SPSS 22 program in table 3 it can be seen that the event variable $(\mathrm{X})$ has a Cronbach's Alpha value of 0.897 and the brand loyalty variable has a Cronbach's Alpha value of 0.944 so that all variables in this study are said to be reliable as Cronbach's Alpha value $>0.6$.

The data analysis technique used in this research is quantitative method analysis techniques using statistical tests consisting of:

\subsection{Descriptive Analysis}

Table 4 Result of Mean Score Event (X)

\begin{tabular}{lc}
\hline \multicolumn{1}{c}{ Dimensions } & Mean Score \\
\hline Involvement & 3,62 \\
Interaction & 3,56 \\
Immersion & 3,60 \\
Intensity & 3,53 \\
Individuality & 3,62 \\
Innovation & 3,71 \\
Integrity & 3,66 \\
\hline \multicolumn{2}{c}{ Sum of Average } \\
\hline
\end{tabular}

Based on table 4, it can be seen that the total average value of the event variable $(\mathrm{X})$ is 3.61 , where the average is close to the maximum value of 4.00 for the scale used in this study is a Likert four scale. This means that the respondent gives a very good assessment for the event variable (X).

Table 5 Result of Mean Score Brand Loyalty (Y)

\begin{tabular}{|c|c|}
\hline Dimensions & Mean Score \\
\hline Make repeat purchases regularly & 3,08 \\
\hline Buy cross-line products and services & 3,14 \\
\hline Referring to others & 2,98 \\
\hline Shows immunity from the attraction of the competitors & 2,13 \\
\hline Sum of Average & 2,83 \\
\hline
\end{tabular}

Based on table 5, it can be seen that the total average value of the brand loyalty variable $(\mathrm{Y})$ is 2.83 , which means that the respondent is at a good level for the brand loyalty variable $(\mathrm{Y})$.

\subsection{Normality Test}

Table 6 Normality Test Results

\begin{tabular}{|c|c|c|}
\hline \multicolumn{3}{|c|}{ One-Sample Kolmogorov-Smirnov Test } \\
\hline & & $\begin{array}{l}\text { Unstandardized } \\
\text { Residual }\end{array}$ \\
\hline $\mathrm{N}$ & & 120 \\
\hline Normal & Mean & 0.0000000 \\
\hline Parameters $^{\mathrm{a}, \mathrm{b}}$ & Std. Deviation & 7.18932967 \\
\hline Most Extreme & Absolute & 0.143 \\
\hline \multirow[t]{2}{*}{ Differences } & Positive & 1.181 \\
\hline & Negative & -0.123 \\
\hline Test Statistic & & 0.173 \\
\hline \multicolumn{2}{|c|}{ Asymp. Sig. (2-tailed) } & $0.890^{\circ}$ \\
\hline \multicolumn{3}{|c|}{$\begin{array}{l}\text { a. Test distribution is Normal. } \\
\text { b. Calculated from data. } \\
\text { c. Lilliefors Significance Correction. }\end{array}$} \\
\hline
\end{tabular}

Based on table 6, it can be seen that the Asymp value. Sig. (2-tailed), namely 0.890 , it can be stated that the data is normally distributed because of the Asymp value. Sig. (2tailed) is greater than 0.05 .

\subsection{Simple Linear Regression Analysis}

Table 7 Simple Linear Regression Analysis Results

\begin{tabular}{|c|c|c|c|c|c|c|}
\hline \multicolumn{7}{|c|}{ Coefficients ${ }^{a}$} \\
\hline & \multirow[b]{2}{*}{ Model } & \multicolumn{2}{|c|}{$\begin{array}{l}\text { Unstandardized } \\
\text { Coefficients }\end{array}$} & \multirow{2}{*}{$\begin{array}{c}\text { Standardized } \\
\text { Coefficients } \\
\text { Beta }\end{array}$} & \multirow[b]{2}{*}{$\mathrm{t}$} & \multirow[b]{2}{*}{ Sig. } \\
\hline & & B & Std. Error & & & \\
\hline 1 & (Constant) & -8.490 & 6,862 & & $-1,237$ & 0,218 \\
\hline & Event & 0,651 & 0,090 & 0,554 & 7,227 & 0,000 \\
\hline
\end{tabular}

Based on table 7 it can be stated that the constant coefficient which is negative is -8.490 , meaning that if the event variable $(\mathrm{X})$ is zero, then the value of brand loyalty $(\mathrm{Y})$ will have a price of $-8,490$ and the event coefficient $(\mathrm{X})$ is 0.651 which means that every addition $1 \%$ event $(\mathrm{X})$ then brand loyalty $(\mathrm{Y})$ will also increase by 0.651 and vice versa. The event coefficient $(\mathrm{X})$ is positive which means that there is a positive relationship between an event $(\mathrm{X})$ and brand loyalty $(\mathrm{Y})$, the higher the event, the greater the brand loyalty.

\subsection{Analysis of The Coefficient of Determination}

Table 8 Simple Linear Regression Analysis Results

\begin{tabular}{ccccc}
\hline \multicolumn{5}{c}{ Model Summary } \\
\hline Model & $\mathrm{R}$ & $\mathrm{R}$ Square & $\begin{array}{c}\text { Adjusted } \mathrm{R} \\
\text { Square }\end{array}$ & $\begin{array}{c}\text { Std. Error } \\
\text { of the } \\
\text { Estimate }\end{array}$ \\
\hline 1 & $0,554^{\mathrm{a}}$ & 0,307 & 0,301 & 7,21973 \\
\hline
\end{tabular}

Based on the results of the coefficient of determination with the help of SPSS 22 in table 8, it can be seen that the R Square value is 0.307 , which means that the event can affect the brand loyalty variable by $30.7 \%$, while the rest is influenced by other variables outside of this study. 


\section{7. $t$-Test}

Based on table 7, it can be seen that the $t$ value is 7.227 greater than the $\mathrm{t}$ table value $(\mathrm{df}=\mathrm{N}-2)$ for 120 respondents with a significant level of 0.05 , namely 1.98027 , it can be stated that $\mathrm{H} 0$ is rejected and $\mathrm{H} 1$ is accepted, which means there is an influence. between the \#TokopediaWIB TV Show event against the Tokopedia Brand Loyalty by K-pop fans in Jakarta. Table 7 also shows that the significant value of 0.000 is smaller than 0.05 , so the event variable has a significant effect on the variable brand loyalty.

The \#TokopediaWIB TV Show event is considered to have fulfilled all the 7i event attributes put forward by Wood and Masterman, this is based on the results of distributing questionnaires that each event attribute obtains an average value which is classified as good so that based on the total average value as a whole, a good assessment is obtained. Which is very good for the \#TokopediaWIB TV Show event. This is in line with Wood and Masterman's statement [6] that an event that has fulfilled the seven-event attributes can be declared a successful event. The variable Brand Loyalty (Y) in this study is based on the characteristics that indicate brand loyalty as stated by Jill Griffin [9]. Based on the results of the questionnaire distribution, it can be seen that the average respondent has a relatively good level of brand loyalty. This is based on the average results of each dimension of brand loyalty being in a high classification except on the dimensions showing immunity to pull from competitors who are in low classifications. If it is linked to the level of brand loyalty [17], it can be stated that the average sample in this study is that K-pop fans have loyalty to Tokopedia, which is in the second-highest level in the brand loyalty pyramid, namely likes the brand, since the average respondent has liked the brand where this liking is based on associations related to symbols, a series of experiences using the brand, or a high-quality perception. Based on the results of simple linear regression analysis, it can be interpreted that marketing communication through events plays an important role in the growth of brand loyalty if it is little or no holding of an event, the growth of brand loyalty can be hampered and conversely an event can encourage an increase in brand loyalty so it can be concluded that events have a positive effect on brand loyalty. This positive influence is further supported by the coefficient of determination test conducted by the researcher, which is that the \#TokopediaWIB TV Show event affects $30.7 \%$ of Tokopedia's brand loyalty, where the rest is influenced by other variables not explained in this study. This is in line with Getz's statement [4] that events organized by a company can affect brand awareness and loyalty. Similar research [9] also proves the same thing that special events are influential in building retail store brand loyalty among generation $\mathrm{Z}$. Based on this and the T-test results it can be stated that there is an influence between the \#TokopediaWIB TV Show event on Tokopedia brand loyalty by K-pop fans in Jakarta.

\section{CONCLUSIONS}

Based on the results of data processing, there are several things that can be seen by researchers, namely the \#TokopediaWIB TV Show program is a form of marketing communication that fulfils every element in communication and participant's point of view, the event has fulfilled all the attributes of the event so that on average the average audience who are K-pop fans provided excellent service to the event. The audience who are K-pop fans have a relatively good level of brand loyalty where if they are in the brand loyalty pyramid, the average K-pop fan is at the second level in the pyramid, namely liking the brand. The \#TokopediaWIB TV Show program has a significant effect on Tokopedia brand loyalty by K-pop fans where the event variable has an effect of $30.7 \%$ on the brand loyalty variable and other variables not examined in this study, so it can be stated that marketing communication through a Marketing activity Public Relations, namely events can encourage increased brand loyalty.

Researchers suggest that further research is expected to conduct more in-depth research on other factors that affect brand loyalty that are not yet known in this study, such as Key Opinion Leaders, Loyalty Programs, advertisements, and others. In addition, researchers also suggest researchers who want to research similar things to review it from the point of view of the organizer so that there are variations with this study that review from the perspective of the participants.

\section{ACKNOWLEDGMENT}

This work was supported by faculty of communications studies, Universitas Tarumanagara, Jakarta, Indonesia

\section{REFERENCES}

[1] J. Jacqueline and S. Kusniadji, "Pengaruh Komunikasi Pemasaran melalui Event dan Iklan terhadap Citra Merek Shopee," Prologia, vol. 2, no. 2, p. 363, 2019, doi: 10.24912/pr.v2i2.3713.

[2] S. Susanto and A. Sari, "Strategi Komunikasi Pemasaran Jam Tangan Matoa dalam Meningkatkan Brand Awareness," SOURCE J. Ilmu Komun., vol. 6, no. 1, pp. 108-117, 2020.

[3] A. Theaker, The Public Relations Handbook. Routledge, 2016.

[4] S. Octavia, "Pengaruh Event Mizzu Lab 2017 Terhadap Brand Awareness Produk Mizzu Valipcious Velvet Matte.” Universitas Multimedia Nusantara, 2017. 
[5] Jati, "Segementasi Mahasiswa Program Studi Ilmu Komunikasi UAJY dalam Menggunakan Gadget (Studi Deskriptif terhadap Mahasiswa Program Studi Ilmu Komunikasi UAJY dengan Teknik Analisis Cluster berdasarkan Motivasi dan Perilaku Penggunaan Gadget)," pp. 1-24, 2014.

[6] F. F. Cahyani, "Pengaruh Event Marketing Arema Goes to School terhadap Brand image Arema FC." Universitas Brawijaya, 2017.

[7] N. J. Setiadi, Perilaku konsumen. Kencana, 2015.

[8] A. R. Wijaya, “Analisis Peran Event Marketing We Starmusic dalam Menjaga Brand Loyalty Bir Bintang Pilsner," J. Ilm. Univ. Bakrie, vol. 3, no. 03, 2015.

[9] I. N. Setyanto, "Pengaruh Event Terhadap Brand Loyalty Toko Ritel Di Kalangan Generasi Z (Survei Terhadap Mahasiswa Pada Cluster Universitas Di Jakarta).” Universitas Multimedia Nusantara, 2018.

[10] R. Ruslan, "Manajemen Public Relations \& media Komunikasi: Konsepsi dan Aplikasi. Jakarta: PT Raja Grafindo PersadaPawito. 2008," Penelit. Komun. Kualitatif, 2012.

[11] N. S. Febriani and W. W. A. Dewi, Teori dan Praktis: Riset Komunikasi Pemasaran Terpadu. Universitas Brawijaya Press, 2018.

[12] F. Sulastri and G. Saleh, "AKTIVITASMARKETING PUBLIC RELATIONS (MPR) DALAM MENINGKATKAN PELANGGAN," Communiverse, vol. 3, no. 1, pp. 31-42, 2017.

[13] Y. Yantimas and D. Ayu Candranigrum, "Analisis Brand Activation Hellobeauty dalam Membangun Loyalitas Konsumen," Prologia, vol. 3, no. 1, pp. 305312, 2019.

[14] S. Rahayu, "Pengaruh Event ESMOD Fashion Festival 2012 Terhadap Citra ESMOD Jakarta," WACANA J. Ilm. Ilmu Komun., vol. 12, no. 3, pp. 241$260,2017$.

[15] F. Husna, "Event Kesenian Sebagai Media Komunikasi Dalam Melestarikan Budaya Daerah," UIN Sunan Kalijaga, 2016.

[16] Y. Oktarina and Y. Abdullah, Komunikasi Dalam Perspektif Teori Dan Praktik. Deepublish, 2017.

[17] J. Natania, "Strategi customer relationship management the body shop indonesia dalam membangun brand loyalty: Studi kasus terhadap program membership love your body periode juli- desember 2013." Universitas Multimedia Nusantara, 2014.

[18] P. D. Sugiyono, "Metode Penelitian Bisnis: Pendekatan Kuantitatif, Kualitatif, Kombinasi, dan R\&D," Penerbit CV. Alf. Bandung, 2017.

[19] J. Hair, W. C. Black, B. J. Babin, and R. E. Anderson, "Multivariate Data Analysis. Global. London: Edition.” Pearson Education, 2010. 